This is an author produced version of a paper published in Land Use Policy.

This paper has been peer-reviewed and is proof-corrected, but does not include the journal pagination.

Citation for the published paper:

Butler, Andrew \& Åkerskog, Ann. (2014) Awareness-raising of landscape in practice. An analysis of Landscape Character Assessments in England.

Land Use Policy. Volume: 36, pp 441-449.

http://dx.doi.org/10.1016/j.landusepol.2013.09.020.

Access to the published version may require journal subscription.

Published with permission from: Elsevier.

Standard set statement from the publisher:

(C) Elsevier, 2014 This manuscript version is made available under the CC-BY-NC-ND 4.0 license http://creativecommons.org/licenses/by-nc-nd/4.0/

Epsilon Open Archive http://epsilon.slu.se 


\section{Awareness-raising of landscape in practice. An analysis of Landscape Character Assessments in England}

\section{Abstract}

Awareness-raising is one of the measures which signatories to the European Landscape Convention are expected to realise, yet it is unclear what awareness-raising entails when related to an ambiguous subject such as landscape. Our study builds a conceptual understanding of awareness-raising of landscape, recognising that it cannot be a purely top-down process but needs to be seen as a "multi-directional transfer of knowledge" or "co-creation of meaning". We have used this conceptual understanding as a lens for analysing practices which in some form help raise awareness of landscape. Document studies of Landscape Character Assessments undertaken in England since 2007 and interviews with key actors involved in Landscape Character Assessments were carried out in order to understand how awareness-raising is addressed. The findings suggest that while often overlooked or recognised as a top down endeavour landscape assessments have potential to develop cocreation of meaning.

\section{Introduction}

The objective of a landscape assessment is to create a representation of landscape for others to argue for its values, providing insight and understanding of place (Stahlschmidt and Nellemann 2009). As such, a landscape assessment signifies an assemblage and subsequent dissemination of knowledge, perceptions and values. The resulting assessment document represents an artefact for promoting an officially recognised expression of the landscape. As a representation of landscape an assessment is integrated into and informs on-going discourse on landscape. The assessment and subsequent development of discourse on landscape is dependent on the knowledge, perceptions and values that are included or excluded, which is subsequently informed by existing discourses.

The assessment document becomes a tool for raising awareness of landscape, expressing officially recognised values and moulding future discourses on the landscape. However, if a democratised view of landscape as enshrined in the European Landscape Convention (ELC) (Council of Europe 2000a) is considered, then awareness-raising can also be seen as an essential part of the assessment process. Rhetoric from the ELC suggests that all individuals have equally valued knowledge of landscape and hence an equal claim to express that knowledge (Jones 2007). Consequently, awareness-raising shifts from being a top down activity to a 
multidirectional transfer of knowledge potentially leading to a co-creation of meaning (Lewis, Pea et al. 2010). Awareness-raising becomes intrinsic to landscape assessment both through the assessment process and as the produced artefact.

To raise awareness requires conscious recognition of the subject matter we are raising awareness of - in this case landscape. This may sound obvious, but landscape is a widely contested and frequently misunderstood concept. Even within disciplines directly engaging with landscape there is an array of theoretical approaches and methodologies for exploring and explaining landscape (Olwig 2007a; Bell, Sarlöv Herlin et al. 2012).

This paper addresses the tensions and contradictions which arise when awareness-raising of landscape is taken into account. The phenomenon is studied by examining Landscape Character Assessments (LCA) (Swanwick 2002) undertaken in England between 2007 and 2012. LCA is a comprehensive approach for analysing landscape used across much of the UK and recognised as an instrument which contributes to the implementation of the ELC (Natural_England 2009). The LCA approach has been utilised as a case study for developing an understanding of what raising awareness of landscape and landscape values means in practice.

This paper begins with a consideration of the definition of landscape laid down in the ELC and then addresses how awareness-raising can be considered in light of the multiple facets that this concept of landscape represents. The LCA approach is then introduced and through both document analysis and semi-structured interviews an understanding of how these issues are addressed in practice is presented. Implications of this are critically discussed and conclusions are drawn, reflecting on the use of awareness-raising for understanding the multiple values of landscape.

\section{Landscape: what are we raising awareness of?}

The European Landscape Convention, adopted by the Committee of Ministers of the Council of Europe in 2000, is the first international regional convention to focus on Landscape as an entity in itself (Council of Europe 2000a; Prieur 2006). As a legislative instrument, the ELC needs an accepted definition of its central subject, landscape. The resulting definition necessitates acceptance across the multitude of disciplines which impinge upon landscape and which already operate within their own legal, policy and theoretical frameworks. The acceptance of the convention as an international legislative tool requires that this definition is also acknowledged across the diverse cultures of the member states of the Council of Europe. To gain such wide 
acceptance and to be appealing to all, the definition needs a high degree of ambiguity (Matland 1995). The resulting definition, recognising landscape as "an area, as perceived by people, whose character is the result of the action and interaction of natural and/or human factors;" (Art 1a) (Council of Europe, 2000a), is consequently open for wide interpretation. This openness, founded upon "a compromise between concepts and perceptions of landscape" (Olwig, 2007b p. 586) allows a broad if somewhat disparate European understanding of landscape to develop and help further the European agenda of "Unity in Diversity" (Pedroli, Wascher et al. 2007; Sassatelli 2010; E.U 2011).The vagueness of the definition also helps to cross disciplinary boundaries as its openness to interpretation allows all to attach their individual understanding to it. The diversity of disciplines and cultures with their own conceptual/theoretical frames and beliefs means landscape cannot fit within a fixed theoretical definition, but must be allowed to develop and morph.

Ambiguity of language may be appealing at a European policy level where the elasticity imbibed in the concept allows a perceived cross cultural understanding, however ambiguity creates the risk of contention when the subject is operationalized (Matland 1995). This contention is compounded by the fact that the ELC definition differs from and may conflict with others understanding of landscape (Antrop 2001; Council of Europe 2008; ESF/COST 2010; Déjeant-Pons 2011). Diversity of concepts and the ambiguity of the ELC are seen as leading to landscape being considered "a fuzzy subject" (Scott, 2011 p2758) which lacks a real advocate for its cause (Jones and Daugstad 1997). The lack of an advocate for a new and positively laden policy subject, such as landscape, can generate greed as disciplines attempt to attain ownership of it (Jones and Daugstad 1997; Sassatelli 2010). This creates space for conflict between the different actors as well as between the ELC definition and the definition operationalised by bodies in member states, working within pre-existing sectoral based legal and policy frameworks.

Academics generally interpret the text of the ELC as a post-modern interpretation of landscape, socially constructed; relating to meanings, symbols and processes rather than to absolute values (Gailing and Leibenath 2013). These are meanings founded on mental and social constructs (Howard 2007; Jones 2007). Such an understanding moves landscape away from being purely an asset and part of physical space, to being linked to people's perceptions (Howard 2004; Planchat-Héry 2011). As the focus moves to landscape as experienced by people, it becomes dependent on the actions and interactions of individuals and society, placing increased emphasis on the inhabitants of landscape and diminishing the dominance of experts (Sarlöv Herlin 2007). As 
such landscape embodies human relations to the physical environment; it represents the site where routines are lived out and places which are often taken for granted (Sack 1997). Consequently landscape becomes an entity through which the environment can be communicated to the public and an arena through which the public can communicate their relationship to their surroundings. Although the public are crucial to an understanding of landscape based on perceptions, the intangible knowledge on which this understanding is based makes the concept ambiguous and not always relevant to people's everyday way of thinking (Soini 2004; Sevenant and Antrop 2010).

From this discussion it becomes clear that when landscape is considered there needs to be acknowledgement of what is actually being addressed. At a European level the idea of landscape develops a concept which all can agree on and helps further the objectives and aims of the Council of Europe; at national and regional level landscape needs to function as a practical tool and an instrument for understanding the phenomena which represents the surroundings to life; while for the public, landscape becomes an arena for discussing and understanding life and an entity on which identity is built (Proshansky, Fabian et al. 1983). None of these meanings of landscape are static, nor do they sit in isolation, each is interdependent with the others as they influence and inform each other.

\section{Awareness-raising}

The concept of landscape ingrained in the ELC means that an understanding of landscape moves from being a more or less visible and tangible entity to being inclusive of the subjective matter of the mind. In such light the importance of the perceptions of those who experience the landscape is drawn into focus. Comprehending the perceptions, meanings and values of a landscape is based on the knowledge and its articulations by those who encounter the landscape. This is recognised within the ELC through its emphasis on the need for participation (Council of Europe 2000a, Art 5c), a topic which has been addressed by numerous researchers (Scott 2002; Selman 2004; Jones 2007; Stenseke 2009; Clemetsen, Krogh et al. 2011; Conrad, Cassar et al. 2011; Jones 2011; Planchat-Héry 2011). In contrast awareness-raising (Art 6a, Council of Europe 2000a), which is also central to an understanding of landscape, is a relatively untouched topic. The convention expresses awareness-raising as one of three specific measures, expecting signatories to the convention to "increase awareness among the civil society, private organisations, and public authorities of the value of landscapes, their role and changes to 
them" (Council of Europe 2000a, Art 6a). This echoes the Council of Europe objective to "promote awareness and encourage the development of Europe's cultural identity and diversity"(Council of Europe 2011). However there is minimal recognition of what this entails.

Existing literature tends to see awareness-raising as a top down approach for promoting the credibility of entities to a community in order to influence both attitudes and behaviours, giving voice to the author of information (UNECE 1998; Carr 2004; Sayers 2006; Burningham, Fielding et al. 2008). Literature addressing awareness-raising tends not to probe the theoretical or conceptual understanding of the activity, instead focusing on normative (Johnson, Penning-Rowsell et al. 2007; Burningham, Fielding et al. 2008) or procedural issues (Read 1999; Carr 2004; Primmer and Kyllönen 2006) and often expressing raising public awareness as a positive outcome when participation fails (Primmer and Kyllönen 2006; Nilsson, Åkerlund et al. 2007).

There is only limited landscape literature relating to awareness-raising. This tends to be ambiguous generally not questioning what values of landscape are being raised or by whom. Many of these studies tend to recognise a top down perspective on awareness-raising, viewing it as; an unintentional positive side effect of participation, where the public is informed what landscape is (Sevenant and Antrop 2010); as an important outcome of participation, for informing on policy (Spencer 2011); or as a prerequisite for successful participation in landscape decision-making (Majchrowska 2011). However there is recognition among some researchers that awareness-raising should be viewed as an exchange between public and experts alike(Olwig 2007b; Conrad, Christie etal, 2011; Jones and Stenseke 2011).

If landscape is considered a concept as defined by the Council of Europe; a perceived entity which is geographically all encompassing and represents the surroundings to people's lives, then raising awareness of the subject can be seen as a typical top down approach. As such authorities and practitioners are informed by the council of Europe, via the ELC, of the meaning of landscape. This approach also accounts for the transfer of the meaning of landscape to society from national, regional and local bodies. The concept of landscape communicated to the public then informs the on-going discourse on landscape. A further element of awareness-raising in a top-down manner is the promotion of the ELC as a legal tool for protecting the surrounding for everyday life. The ELC will not sway power unless it is accepted, understood and used by the public as well as experts, subsequently landscape as championed by the convention is promoted. 
While this top down approach is necessary for passing on a common understanding of the ELC and its concept of landscape, it contradicts the democratic principles and definition outlined within the ELC (Council of Europe 2000a; Prieur 2006). This issue is recognised in the guidelines for implementation of the convention (Council of Europe 2008) and has been taken up by Olwig (2007b); and Conrad et al. (2011). The guidelines acknowledge that awareness-raising of landscape is more complex than purely informing society; it should represent a multidirectional transfer of knowledge between civil society, private organisations and public authorities. As a multidirectional process, awareness-raising can be seen as giving voice to all who have a stake in landscape, helping to develop a common understanding of the values attached to landscape. seen in this, light awareness-raising changes the understanding of individuals involved and at the same time changes the understanding of the social units or communities which the individuals belong to. Once an individual's intimate understanding of an entity is scrutinised that entity will never be the same again (Polanyi 1966). This, we propose, elevates awareness-raising, in this context from purely promotion of information to social learning (Reed, Evely et al. 2010).

Prior to the concept of landscape being transmitted to wider society it needs to be accepted by the authorities or professionals engaging with the public (figure 1, point 3). Authorities are constituted of individuals with varying degrees of power and differing values (Matland 1995). It is within such a context, consisting of existing, multifarious understandings that the concept expressed in the ELC has to be interpreted and possibly accepted, amended or reformulated. At this point the focus is on the practitioners and authorities sharing understanding and developing a metanarrative of "Landscape". This requires multidirectional awareness-raising of the various meanings of landscape in order to develop a narrative to engender understanding and create a shared language on which commonalities can be built (Nonaka and von Krogh 2009). The concept of landscape ultimately accepted and transmitted by the authorities and professionals needs to be a practical concept, an analytical instrument for addressing landscape as a phenomenon. By analytical instrument we mean that to understand the values which can be attached to a landscape we need to understand what "Landscape" "is" and therefore recognise which values are given voice; creating the frame in which landscape is realised. The definition of landscape recognised by the authorities is accepted as official discourse, a discourse which will frame future discussions on landscape and establish the extent of landscape as an 'arena'. This is 'landscape' as the public will meet the concept when they engage in local landscape issues, relating to their everyday surroundings. 
The concept of landscape recognised by the ELC provides an arena where individual's subjective encounters with their surroundings can be discussed and expressed. Knowledge relating to these encounters is predominantly tacit (Tuan 1977; Ingold 2000; Tilley 2004); it is subjective knowledge, embedded in actions, routines, values and emotions; knowledge about the "here and now". This differs from explicit knowledge which is objective and can be expressed and codified; knowledge of the "then and there" (Polanyi 1966; Nonaka and von Krogh 2009). As all individuals possess knowledge on landscape, so the entire populace are both authors and recipients of information on landscape. Consequently the knowledge of all individuals is equally contestable as truth, as is the knowledge of "experts". For knowledge to be accepted as truth or "justified true belief" it needs to be justified by the individual. Justifying knowledge requires that it is made explicit; this necessitates codifying and expressing tacit understanding. As such knowledge is externalised, facilitating a broader, shared understanding of the topic. This allows individuals, experts and public alike, to reflect on their own understanding and question the taken for granted (Nonaka and von Krogh 2009). This assists the development of a joint understanding, and helps facilitate the acceptance of 'others' landscape related values.

Seen as a "knowledge-spreading process operating in all directions" (Council of Europe 2008: II,2,3,B), awareness-raising becomes central to producing a co-creation of meaning (Lewis, Pea et al. 2010). Co-creation of meaning can be used to describe the process which occurs when developing discourses on individual landscapes "... as perceived by people" (Council of Europe 2000a) and constituting the surroundings for their everyday life. In this multidirectional approach, all are involved in the co-creation of meaning, redefining what their landscape represents. This is what Kenneth Olwig refers to as the 'conventional' meaning of landscape which has arisen from perceptions, interests and practices, an understanding of landscape shaped by "public discursive practice, rather than scientific reasoning" (Olwig, 2007b p.580).

Public discourses on individual landscapes expand existing knowledge and in turn influence the meta-narrative providing practitioners with the locus to reflect and readdress their own values and views (Schön 1983; Nonaka and von Krogh 2009). As such, neither the perceived landscape nor the concept of landscape are static entities. From this it follows that the convention which defines the concept must also be dynamic. The Council of Europe acknowledges this, recognising that the ELC should be "dynamic, evolving alongside the subject matter... keeping pace with changes of values and interests" (Council of Europe 2000b). This redress of the ELC 
may be achieved through researchers analysing practitioners' approaches. In this light there can never be a final correct view of landscape as concept is only trustworthy at a specific point at a given time (Nonaka and von Krogh 2009). As perceptions change so do the values and criteria for understanding the landscape, subsequently awareness-raising of landscape becomes an on-going process; a continuous dialogue.

In this section we have highlighted the multiple aspects of awareness-raising from the ELC perspective; from informing to social learning, depending on what aspect of landscape is considered. However, while this paper considers awareness-raising per se, it is how the public is informed of landscape, i.e. how landscape is framed; and how the public are engaged in multidirectional awareness-raising which is the focus of the empirical data.

\section{Landscape Character Assessments as a means of understanding awareness-raising of landscape.}

To see how awareness-raising is applied in practice, we have drawn on Landscape Character Assessment (LCA), an approach for assessing the landscape and subsequently a mechanism for maintaining, enhancing or altering discourse on landscape. The LCA approach prevails through much of the UK where it is recognised as a tool for implementing the ELC (Natural_England 2009). This approach is also used to varying degrees in other European countries (Swanwick 2009). Since the LCA approach in the UK is recognised as assisting implementation of the ELC it should be expected that it will be in line with the ELC both with regards to how landscape is considered and consequently the significance of public involvement including awareness-raising.

The main supporting document for LCA's in the UK is the guidance from 2002 (Swanwick 2002). In the guidance text a similar concept of landscape to that contained within the landscape convention is expressed "... the relationship between people and place ... the setting for our day-to-day lives" and that "People's perceptions turn land into the concept of landscape" (Swanwick 2002: 2-3). As with the ELC's definition, this places perception and thus meaning and values as central to understanding landscape; landscape as a social construct.

Both the guidelines and supporting topic paper, “Topic Paper 3: Landscape Character Assessment: how Stakeholders can help" (Swanwick, Bingham et al. 2002) explicitly emphasizes the need to engage the public. However, mention of awareness-raising in the guidance and supporting literature, is summarised in the following text "[t]his then stands as a neutral statement of the current character of the landscape. This can be used to raise awareness of the distinctiveness of the landscape and encourage appreciation of the differences 
between individual areas" (Swanwick 2002:13). This sees awareness-raising as a product of the document rather than a phenomenon tied up in the process of the assessment. Such a consideration for awarenessraising, irrespective of the definition of landscape it builds on, has to be viewed as top down, informing directly from the assessment document and missing the opportunity to develop a common understanding of landscape.

The definition of landscape expressed in the assessment documents is a representation of the officially recognised concept of landscape, acknowledged by the commissioning authorities. The definition consequently informs the basis for the assessment, identifying which values of landscape are included or excluded and subsequently what awareness-raising entails.

\section{Method}

The LCA guidelines constitute part of the frame in which the LCA approach can be understood. However the LCA guidance and supporting literature, which was informed by best practice is now over a decade old and cannot truly represent contemporary practice. In this light we examine how recent LCA's define and respond to awareness-raising and landscape in practice.

We assessed publically accessible LCA documents undertaken between 2007 and 2012 in England. 78 documents in total were viewed. The year 2007 was chosen as the start date for reviewing the documents as it corresponds with the year that the ELC became binding in the UK (March 2007). Although many of the assessments started prior to this date, it can be considered that the rhetoric of the ELC had already been in position since ratification in 2006. Documents were initially identified through the Natural England database for LCA's, archived since November 2010 (Natural-England and Countryscape 2010) and accessed via the respective authorities' home page between $25^{\text {th }}$ of February and $25^{\text {th }}$ of April 2011. Assessments after November 2010 were attained by undertaking an internet search and consequently accessing the documents through the commissioning authorities' home page between $10^{\text {th }}$ January 2013 and $1^{\text {st }}$ of February 2013 . The LCA's accessed range from local to county wide assessments.

The assessment documents were analysed in order to gain a broad yet coarse understanding of the present state of affairs. We had four focuses for our document analysis: definition of landscape expressed in the documents; reference to the ELC; inclusion of various forms of stakeholders; and consideration of awarenessraising. 
- In relation to the definition of landscape expressed in the documents we assessed if it is: a visual and physical understanding; if cultural associations of landscape have been considered; or if landscape is seen as a perceived entity.

- With reference to the ELC we were interested not just in whether the convention was taken up but what was drawn from the convention: acceptance of ELC definition, recognition as a legislative tool, or reliance on people to form an understanding of landscape.

- The assessments were studied for how the rhetoric around perceptions of the landscape were translated into practice; whether those who directly experience landscape (communities of place); and those who have an interest which is located in the place (communities of interest) and based on explicit knowledge, were included.

- We then assessed if the issue of awareness-raising had explicitly been addressed in the text.

The document study identified good practice examples, where the public were engaged with the possibility of transferring knowledge. These examples were followed up through semi-structured interviews. Additional examples of good practice were identified through "snowball technique" to identify other actors who had undertaken work which had not been recognised, either being undertaken earlier than the date stipulated or using an approach which was not professionally driven e.g. Community LCA's.

Semi-structured interviews were held with seven actors who discussed 14 different assessments which they had been involved with. The informants constituted NGO's representatives involved with community driven landscape assessment (one interviewee); county administrative employees responsible for county wide assessments and also influential at local authority level (three interviewees); and practitioners working at varying scales (three interviewees). The interviews lasted between one and two hours and were transcribed and analysed by the authors. Questions included:

- How do you explain the term landscape when working with the public?

- What was the purpose of involving the public?

- In what way is awareness-raising considered when engaging the public in landscape assessments? 


\begin{tabular}{|c|c|c|c|c|c|c|c|}
\hline Name & Year & ELC & Visual/ & Multiple & Perception & \multicolumn{2}{|c|}{ Stakeholder involvement } \\
\hline & & & & & & place & interest \\
\hline Ashford Landscape Character & 2011 & No & Yes & Yes & Yes & No & No \\
\hline Aylesbury Vale LCA & 2008 & No & No & No & No & No & No \\
\hline Bassetlaw LCA & 2009 & No & Yes & No & No & No & No \\
\hline Blaby District Character Assessment & 2008 & No & No & No & No & Yes & Yes \\
\hline Bedford Borough LCA & 2007 & No & No & No & No & Yes $^{\mathrm{b}}$ & Yes \\
\hline Boston Borough LCA & 2009 & Yes & Yes & Yes & Yes & Yes & Yes \\
\hline Bradford LCA & 2008 & No & Yes & Yes & No & No & Yes \\
\hline Broadland District Council LCA & 2008 & Yes & Yes & Yes & Yes $^{a}$ & No & Yes \\
\hline Charnwood Borough LCA & 2012 & Yes & Yes & Yes & Yes $^{\mathrm{a}}$ & No & No \\
\hline Cheshire LCA & 2008 & No & No & No & No & No & No \\
\hline Churnet Valley LCA & 2011 & No & No & No & No & No & No \\
\hline Cornwall and Isles of Scilly LCA & 2007 & No & Yes & Yes & No & Yes & Yes \\
\hline County Durham LCA & 2008 & Yes & Yes & Yes & $Y_{e s}{ }^{a}$ & No & No \\
\hline Coventry Urban Fringe LCA & 2007 & No & No & No & No & No & No \\
\hline Cumbria Landscape Character Guidance & 2011 & Yes & Yes & Yes & Yes & No & No \\
\hline Dartmoor National Park LCA & 2010 & Yes & Yes & Yes & Yes & Yes $^{b}$ & Yes \\
\hline Dorset LCA & 2010 & No & No & No & No & No & No \\
\hline Dorset AONB LCA & 2008 & Yes & Yes & Yes & $Y_{e s}{ }^{a}$ & $Y_{e s}^{b}$ & Yes \\
\hline East Devon and Blackdown Hills AONB LCA & 2008 & No & No & No & No & No & No \\
\hline East Dorset LCA & 2008 & No & No & No & No & No & No \\
\hline East Herts District LCA & 2007 & Yes & Yes & Yes & Yes & Yes & Yes \\
\hline East Lindsey District LCA & 2009 & Yes & Yes & Yes & Yes & Yes & Yes \\
\hline Eastleigh Borough LCA & 2011 & Yes & Yes & Yes & Yes $^{a}$ & No & No \\
\hline Forest of Bowland Area of Outstanding Natural Beauty LCA & 2009 & yes & yes & Yes & Yes & No & Yes \\
\hline Forest Heath LCA & 2008 & No & Yes & No & No & No & No \\
\hline Great Yarmouth Borough LCA & 2008 & No & No & No & No & Yes $^{b}$ & Yes \\
\hline Guildford LCA & 2007 & No & No & No & No & Yes & Yes \\
\hline Hambleton and Howardian Hills LCA & 2007 & No & No & No & No & Yes & Yes \\
\hline Hampshire County Integrated Character Assessment & 2010 & Yes & No & No & No & No & No \\
\hline Harborough District LCA & 2007 & No & No & No & No & No & Yes \\
\hline Havant Borough LCA & 2007 & No & Yes & Yes & No & Yes & Yes \\
\hline
\end{tabular}




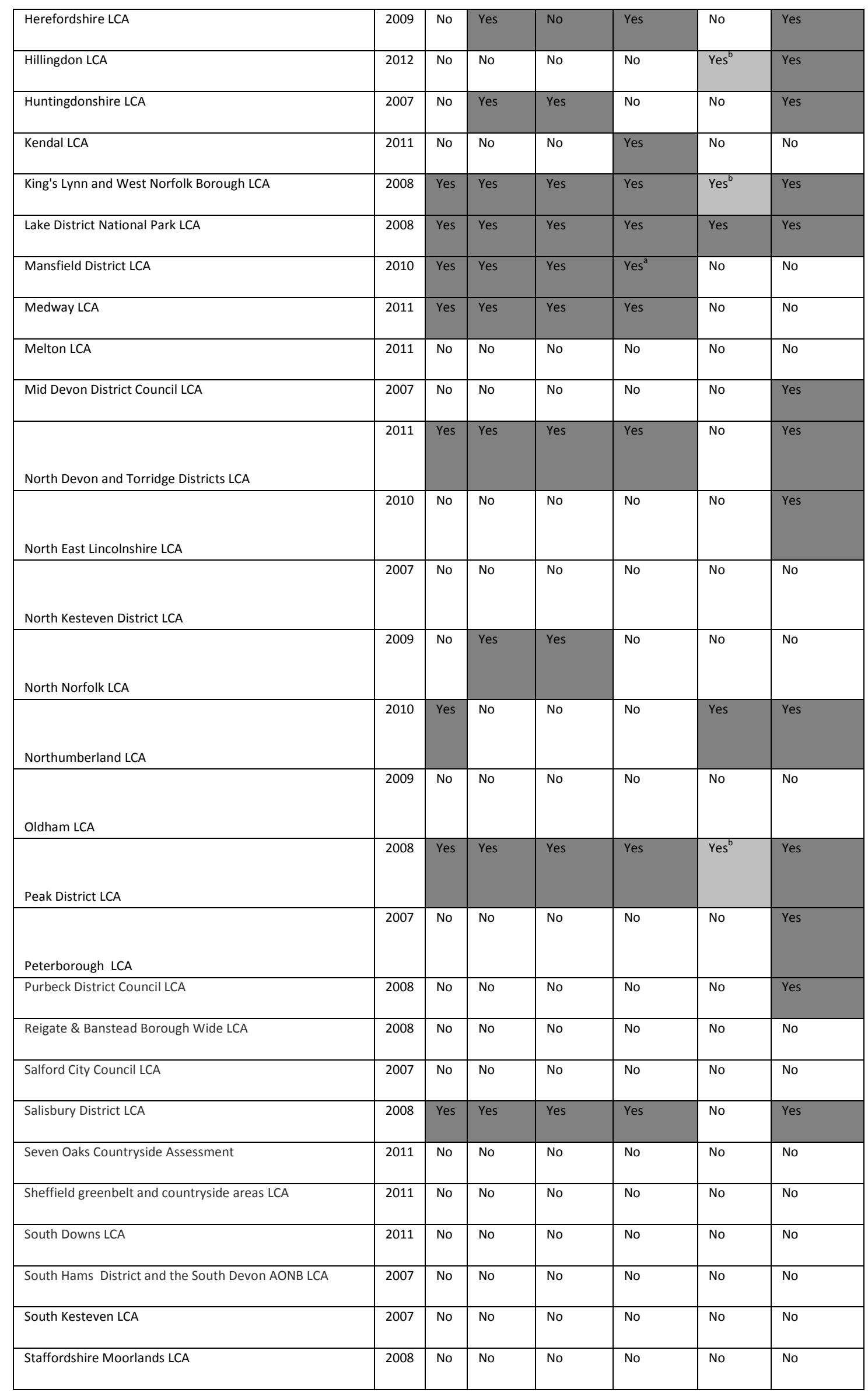




\begin{tabular}{|c|c|c|c|c|c|c|c|}
\hline Stockton on Tees LCA & 2011 & No & No & No & No & Yes & Yes \\
\hline Suffolk LCA & 2008 & No & No & No & No & No & No \\
\hline Swindon LCA & 2011 & No & No & No & No & No & No \\
\hline Taunton Deane LCA & 2011 & Yes & No & No & No & No & No \\
\hline Teignbridge District LCA & 2008 & Yes & Yes & Yes & Yes $^{a}$ & Yes & Yes \\
\hline Torbay LCA & 2010 & Yes & Yes & Yes & $Y^{a} s^{a}$ & Yes $^{b}$ & Yes \\
\hline Tunbridge Wells Borough LCA & 2009 & Yes & Yes & Yes & Yes & No & No \\
\hline Tynedale District and Northumberland National Park LCA & 2007 & No & No & No & No & No & No \\
\hline Vale Royal LCA & 2007 & No & No & No & No & No & No \\
\hline Warrington Borough LCA & 2009 & No & No & No & No & No & No \\
\hline Warwick and Leamington & 2009 & No & No & No & No & No & No \\
\hline Waveney District LCA & 2008 & No & No & No & No & Yes & Yes \\
\hline Wellhead Valley LCA & 2011 & Yes & Yes & Yes & Yes & No & No \\
\hline West Dorset LCA & 2009 & No & No & No & No & No & Yes \\
\hline Weymouth and Portland LCA & 2012 & No & No & No & No & No & no \\
\hline West Wiltshire LCA & 2007 & Yes & Yes & Yes & Yes & No & Yes \\
\hline Wigan Borough Council LCA & 2009 & No & Yes & No & No & No & No \\
\hline Wirral LCA & 2009 & No & Yes & Yes & Yes & Yes & Yes \\
\hline Worcestershire LCA & 2011 & Yes & Yes & Yes & Yes $^{a}$ & No & No \\
\hline
\end{tabular}

\section{Document Results (Table 1)}

Awareness-raising is rarely explicitly mentioned in the assessment documents. Where it is recognised it is seen as a way of promoting the project: "Raising the general awareness in the planning process of the importance of landscape character in contributing to quality of life within the Borough by recognizing..." (King's Lynn and West Norfolk $L C A)$; or to forward specific professional facets of the landscape: “...awareness about historic and cultural associations" (East Lyndsey LCA).

However, fundamentally all of the assessments helped raise awareness of the landscape, as they can be accessed from the commissioning authorities' websites and contain a description of the landscape. This represents top-down awareness-raising of the lived landscape; all who access the document are informed that this is how their landscape is. While all these documents inform on landscape the values which are recognised 
vary greatly. This is explicitly conveyed in the spectrum of definitions of landscape across the different assessments.

Of the 78 assessments accessed 43 do not provide a definition of landscape. This makes it difficult to appreciate what values are being taken up. It does not necessarily mean that the multiplicity of values is ignored, but that the documents lack transparency of what they are assessing.

Of the LCA's which contained a definition of landscape (35), three defined it only as a visual and physical entity. An example of this is Forest Heath LCA: "Landscape is a product of lots of different factors ranging from the topography (hills, valleys, fens etc.), which is influenced by underlying geology, climate and soil type, through land-cover (types of agriculture, whether wooded or not etc.), settlement (farms, villages and towns), through to smaller elements such as the size of fields and the presence or absence of hedges right down to single features such as a church or water-tower." Such a definition, delimits the values which can be attached to landscape, pointing to an outsiders perspective. Awareness-raising in such a context is predominantly a top down process based on explicit knowledge, recognisable by professionals. In such a context a professional discourse of landscape is reinforced.

Five assessments depict landscape as a representation of cultural and nature values and the interactions between these. An example of this is Huntingdon District LCA: “... shaped by a combination of natural processes and human influences, and exhibit features from different stages in their history and development. For example, a specific landscape may include rocks which might be millions of years old, a medieval village, and young trees planted only last week. The particular combination of influences provides each landscape with a unique identity". This expands the understanding of landscape to recognise the influence of people in creating the landscape and their centrality to future landscapes. Yet such a definition is still based on explicit knowledge and misses the meaning attached to landscape by those who directly experience it.

The remaining 28 assessments express landscape as a perceived entity. Nine of the assessments contained the definition from the ELC while the rest of the assessments elaborate on this; for Example the Peak District LCA: "Landscape is more than just 'the view'. It is about the relationship between people, place and nature. It is the ever-changing backdrop to our daily lives. It can mean a small patch of urban wasteland as much as a mountain range, and an urban park as much as a lowland plain... results from the way that different components of our 
environment - both natural and cultural - interact together and are perceived by us." (Highlights by authors). Such a description points to a recognition of the need to understand the tacit knowledge possessed by those experiencing the landscape.

Only 27 of the LCA's accessed referred to the ELC and of those only five considered the wider significance and implications of the convention. It is only from these five assessments where it can be seen that the potential of the ELC as a legislative tool is recognised and promoted. The other assessments used the ELC to frame the assessment in a wider policy context.

While all assessments have described the landscape, those not engaging stakeholders have expressed a professional image of landscape, continuing the understanding of landscape as a top down construct. In these cases awareness-raising is purely a process for informing the public.

Stakeholders were engaged in defining the landscape in 35 of the assessments, of these, 14 involved only communities of interest. The remaining 21 involved both communities of interest and place, although seven engaged only representatives of communities of place. The involvement of stakeholders provides the opportunity for enhanced top down awareness-raising, by enhancing stakeholders understanding of what landscape is. At the same time it provides the opportunity for creating an arena for co-creation of meaning or multidirectional awareness-raising.

The 25 LCA's involving both communities of place and interest were not necessarily the same that expressed landscape as a perceived entity. In fact only 10 of the assessments which recognised landscape as a perceived entity involved those who directly experience that landscape (community of place). Additionally only 15 of the 26 assessments which referred to the ELC engaged any type of stakeholder and only eight involved communities of place.

\section{Interview response - conversation with practice}

The above results highlight how awareness-raising of landscape is presented and functions in the assessments as artefacts. The document study has provided a broad picture of the subject and has raised several questions. To gain a better understanding of what can occur during the assessment process, we looked more closely at assessments which engaged stakeholders - predominantly those with intimate, tacit knowledge of the landscape 
(Communities of place). The aim was to identify the intentions behind the process and comprehend what awareness-raising of landscape entails in practice. The results of the interview study help to address some of the questions arising from the document analysis.

Several of the documents directly refer to awareness-raising, yet as noted earlier this relates primarily to the benefits of the assessment rather than to the concept of landscape or making people attentive to the relevance of their surroundings. What awareness-raising could be was probed further in the interviews. When questioned directly, the informants' recognised it as a traditional informing activity and as an important aspect in initiating stakeholder involvement. It was seen as an opportunity to explain landscape as the medium for assessment. Awareness-raising was also recognised by the majority of those interviewed as being important for informing about the project itself. Raising awareness of the concept of landscape informed stakeholders of the scope of the assessment and thus helped to frame the assessment process.

As artefacts all of the LCA's raise awareness of individual landscapes. However assessments which do not explicitly define landscape, thus omitting what the frame for the assessment entails lack transparency, if the topic is ill defined the ability to raise awareness of it becomes questionable. Provided with the opportunity to elaborate on what landscape means the informants showed consensus on it being a holistic entity including natural, cultural and perceptual aspects. As such they saw that landscape has the opportunity to bring together a diversity of interests which affect or are affected by landscape; as one county official commented: "it's a subject that brings all of the separate, if you like, ologies and what have you together". This recognises the opportunity for multi-directional awareness-raising of the meta-narrative of landscape. Such awareness-raising requires that a tacit understanding of landscape is communicated.

The interviewees had all involved the public in the assessment process, so it comes as little surprise that they viewed the values of those who encounter the landscape first hand as significant for understanding landscape, for "...get[ting] that local sense of meaning" (consultant). Emphasising the possibility to reveal what landscape is to those who dwell in it.

While all those interviewed recognised benefits from involving the public, it was acknowledged that it is problematic to communicate the concept of landscape to the public. This was grounded in the ambiguity of the word and its multiple meanings in the English language. It was recognised that to the layman landscape often 
seems to relate to activity in the garden or concerning only rural areas: “... the green bit is the landscape and [it] doesn't relate to the cultural aspects and also that it relates largely to the visual aspects of perceptions rather than everything"(consultant). To engage the public and get around this ambiguity, there was realisation that the discussion should not get hung up on the concept of "landscape". One consultant recognised the need to approach people on their own terms, rather than getting caught up in specific definitions, they suggested:

"...it is better to introduce landscape by talking about sense of place, rather than by talking about landscape in itself..." (consultant). This appears counterproductive in terms of informing the public of landscape as a concept and advancing the ELC. However it provides the opportunity to share understanding of the values which others place on the landscape, which lies at the heart of the ELC. So although not informing the public of what is landscape, they do provide the public the opportunity to enhance the official discourse on landscape.

Two of the informants openly recognised the significance of highlighting the ELC as a legislative tool. They expressed the need to gain public acceptance in order to realise the potential of the ELC "... certainly the people involved understand what the convention is or is not and wanted that to go in because 'who knows it might help us'” (NGO). Thus the public is informed that there is a mechanism at their disposal for addressing the surroundings to their lives and that their everyday landscapes have significance.

Among the informants there was realisation that both the landscape assessments document itself and the process helped raise awareness and subsequently alters individuals and societies perceptions of the landscape. Consequently stakeholder involvement was seen as more than just adding information to the assessment. Engaging the public with their local landscape was viewed as helping develop a broader understanding of landscape for all involved. One consultant considered landscape as an arena through which people can understand and thus express their surroundings: "if you get people thinking about landscape in its broader sense it's a really positive ... it gets people to step back and think about their place in its broader context"(consultant). It was seen that such engagement would allow the public to get something out of the process as individuals, to gain an appreciation of what they take for granted. It was also considered that local knowledge would add to the professionals' understanding and expand knowledge beyond the project, developing the experts understanding of landscape, thus constituting a degree of multidirectional awarenessraising. 
Even though many of the LCA's were informed by the public, they still retain a predominantly expert focused discourse on landscape, representing professional tools. This is exacerbated in the assessments which have a strong single aspect focus, be it planning or conservation. Interviewees recognised that the focus and constraint of the assessment was evident in many project briefs, one of the interviewees noting "I suppose ... more cynically that there are different motivations for carrying out landscape character assessments and you can often tell viewing the project brief... what the main motivation is. I think that ones that are purely planning policy lead will sometimes be more focused on trying to get outcomes that plug directly in to planning systems and that perhaps that the thought of running another consultation for landscape character assessment is not that appealing" (consultant). Thus the focus of the assessment is seen as the finished product rather than the process or the possible outcomes from the process (i.e. awareness-raising).

It became apparent both through the document analysis and interviews that the form and extent of awareness-raising dependents on if, how and at what stage stakeholders are engaged. Early engagement was viewed as desirable, even providing the opportunity to help define the arena for assessment and providing extended opportunity to develop dialogue. One of the consultants who engaged the public early in the process recognised that “... it shouldn't just be 'yes this is your landscape' it should be that everybody [is] involved... and get them involved in understanding it [landscape]". In such a way early engagement, including defining what the subject of assessment is, helped inform which values are to be included in the assessment and allow for a co-creation of meaning.

Awareness-raising was accepted as a hidden outcome, a 'soft gain' which is difficult to measure as one county official said "Sometimes it's difficult to point to what it achieved,". But discourse on landscape has to be an ongoing process, as one consultant recognised: "if you see landscape character assessment as being more of a process... it's a way of understanding the landscape but perhaps not perfectly... acknowledging the fact that it is always going to be contested, that it's much better to focus the attention of the community involvement on looking at that [contested views]" (consultant).

\section{Discussion on awareness-raising in LCA's}

It is self-evident that the LCA documents act as instruments for awareness-raising; they promote individual landscapes and provide the potential for promoting the concept of landscape. Although it is possible to access 
these texts their existence is rarely widely promoted by the authorities. A Lack of knowledge of the existence of the documents among the public retains the assessment in the professional domain. As was stated in the interviews, the assessments tend to be viewed as professional tools, often focusing on single issues of planning or conservation. As such they fail to recognise the potential of the assessment document as a tool for awareness-raising. Yet many of the assessments are both well written and represent an extremely informative source of knowledge on specific landscape (see for example Peak District Landscape Character Assessment (Peak District National Park Authority 2000)) providing a potential resource of general interest and knowledge on the landscape.

In light of conflicting understandings of landscape (Olwig 2007a; Bell, Sarlöv Herlin et al. 2012), the fact that less than half of the assessments defined landscape, makes it difficult to comprehend exactly what is being assessed. The lack of definition or defining landscape in a restrictive manner also misses the opportunity to spread an understanding of landscape as defined by the ELC i.e. the surroundings to people's lives. In many instances where landscape is defined the documents show a disparity between the definition and how individual landscapes are actually addressed; landscape being defined as a perceived entity yet lacking the perspective of those who experience the landscape. This supports Conrad, Cassar et al.(2011) conclusion that landscape is based disproportionately on expert opinions. Conversely, our study showed that how landscape is understood by the experts interviewed far surpasses what is expressed in the assessment documents. It becomes clear from both the documents and interviews that while landscape may not have been expressly defined as an entity reliant on perceptions, it does not necessarily mean that the views of the public were ignored. What it does mean is that if the definition is not clarified then it is uncertain what public involvement entails and therefore it is unclear what the process can raise awareness of.

In the case of the majority of the documents studied, the public have not been involved in the process; therefore it is a professional image of landscape which is promoted. It is unlikely that this professional view will reflect the values which inhabitants attach to their own local landscapes (Vouligny, Domon et al. 2009) and will maintains awareness-raising as a top-down informing process. Neglecting the public view leads to a failure to recognise diverse and conflicting values bound up in landscape and sees it as a relatively harmonious and static entity (Egoz, Makhzoumi et al. 2011). Such a formulation of landscape is contra to that contained within the ELC (Council of Europe 2000a). 
Our research points to the LCA as a professional tool, with the lack of stakeholder involvement forwarding a professional discourse. This coupled with the lack of promotion of the existence of many of the documents keeps both the assessment and landscape firmly within the professional domain.. Such practice is obviously counter to the ELC, as recognised by Olwig (2007b). The bias towards professionals is compounded by the lack of recognition for the ELC or minimal acknowledgement of its significance as a legislative instrument within the documents, thus restricting awareness of the convention in public realm. As a consequence of this the European Landscape Convention also rests in the professional domain, seen as a tool for experts in the field of landscape and enhancing justification for those professions (Jones and Daugstad 1997; Sassatelli 2010).

Retention of landscape in the professional domain could go part way to answering why awareness-raising is predominantly viewed as an informing process rather than as a way for all to share an understanding of a common resource. Not recognising public values means that the official discourse on landscape remains in the domain of the expert, even though the discourse impinges on the identity of those who experience that landscape. This has been observed by other researcher e.g. Conrad, Cassar et al. (2011) and Scott (2011).

Awareness-raising as multi-directional knowledge spreading between experts, authorities and public can only occur between those who engage in the assessments. This can provide an arena for awareness-raising through personal contact between local people affected by and affecting the landscape. Subsequently a shared understanding of the values attributed to a landscape can develop and a co-creation of meaning be engendered. Including the public in the process does not necessarily denote that awareness-raising has been multidirectional, for example public involvement may be purely consultation. It is only when parties are engaged in a dynamic and discursive process that the opportunity for multidirectional awareness-raising and developing a co-creation of meaning arises. When awareness-raising is seen as multidirectional it can provide the opportunity to address the pluralities which exist in an arena, and do so relatively free from power issues before conflict is manifested (Mouffe 1999; Pløger 2004).

Literature within landscape which deals with awareness-raising is sparse and tends to be ambiguous often only mentioning it in relation to participation. As was mentioned earlier awareness-raising tends to be seen as a top-down process and an indirect outcome of participation (Sevenant and Antrop 2010; Majchrowska 2011; Spencer 2011). From our study of LCA's in England we have recognised that this is also the predominant viewed 
in practice. Top-down awareness-raising can only be a contradiction if trying to promote landscape as recognised in the ELC; how can an entity perceived by people be assessed without addressing those who experience it.

However examples of awareness-raising as a mutual exchange of knowledge as recognised by Olwig (2007b), were also evident to a degree. Awareness-raising of landscape as a multi-directional exchange is dependent on acceptance, by the authorities involved, that landscape is seen as an entity “...as perceived by people...”

(Council of Europe 2000a). Those who engaged in some form of multidirectional awareness-raising expressed a view of landscape dependent on people both through the rhetoric (how landscape was handled in text) and through their actions (their engagement of stakeholders).

\section{Conclusion}

In order to develop an understanding of individual landscapes and what they mean to those who experience them, there is a need for landscape to be accepted as a democratic entity. As Scott (2011) concludes "It is time to break with convention and to boldly go beyond the rhetoric to ensure that we can collectively achieve the kind of landscapes that people want". To achieve the landscape that people want requires awareness of the values and aspirations attached to those landscapes.

Ultimately awareness-raising is meant to influence attitude and therefore it will alter how the landscape is perceived, yet if this does not entail co-creation of meaning then landscape remains in the professional domain. There is a need to make the tacit explicit in order to be able to understand the subject that is being promoted and also to enable those experiencing a landscape to justify their opinions and values. This does not mean that the aim of awareness-raising of landscape should be to create a single common understanding of landscape; it can just as well be used as a means for questioning the authority of those who define what landscape is.

\section{References}

Antrop, M. 2001. The language of landscape ecologists and planners: a comparative content analysis of concepts used in landscape ecology. Landscape and Urban Planning. 55(3), 163-173.

Bell, S., Sarlöv Herlin, I., Stiles, R. 2012. Introduction: landscape architecture in a changing world. In: Bell, S., Sarlöv Herlin, I., Stiles, R. (Eds.), Exploring the boundaries of landscape architecture. Routledge, Abingdon. pp 114 
Burningham, K., Fielding, J., Thrush, D. 2008. 'It'll never happen to me': understanding public awareness of local flood risk." Disasters. 32(2), 216-238.

Carr, A. 2004. "Mountain Places, Cultural Spaces: The Interpretation of Culturally Significant Landscapes." Journal of Sustainable Tourism. 12(5), 432-459.

Clemetsen, M., Krogh, E., Halvorsen Thorén, K. 2011. Landscape perception through participation : developing new tools for landscape analysis in local planning processes in Norway. In: Jones, M., Stenseke, M. (Eds.), The European Landscape Convention : challenges of participation. Springer, Dortrecht. pp 219-237.

Council of Europe. 2011. Council of Europe in brief." http://www.coe.int/aboutCoe/index.asp Retrieved: $11 / 07 / 2012$.

Council of Europe. 2000a. European Landscape Convention. Florence, Strasbourg: Council of Europe. CETS No 176. http://conventions.coe.int/Treaty/en/Treaties/Html/176.htm. Retrieved 10/11/2012.

Council of Europe. 2000b. European Landscape Convention: Explanatory Report. Florence, Strasbourg, Council of Europe. CETS No. 176. http://conventions.coe.int/Treaty/en/Reports/Html/176.htm. Retrieved 10/11/2012.

Council of Europe. 2008. Recommendation CM/Rec(2008)3 ofthe Commitee of Ministers to mamber states on the guidelines for the implementation of the European Landscape Convention. https://wcd.coe.int/ViewDoc.jsp?Ref=CM/Rec(2008)3\&Language=lanEnglish\&Ver=original\&Site=CM\&BackColo rlnternet=9999CC\&BackColorIntranet=FFBB55\&BackColorLogged=FFAC75. Retrieved 01/04/2011.

Conrad, E., Christie, M., Fazey, I. 2011. Understanding public perceptions of landscape: A case study from Gozo, Malta. Applied Geography. 31(1), 159-170.

Conrad, E., Cassar, L.F., Jones, M., Eiter, S., Izaovičová, Z., Barankova, Z., Christie, M., Fazey, I. 2011. Rhetoric and Reporting of Public Participation in Landscape Policy. Journal of Environmental Policy \& Planning. 13(1): 2347.

Davoudi, S., Strange, I. 2009. Conceptions of Space and Place in Strategic Spatial Planning, The RTPI Library Series, 17, Abingdon, Oxon, Routledge.

Déjeant-Pons, M. 2011. The European Landscape Convention: from concepts to Rights. In: Egoz, S., Makhzoumi, J., Pungetti, G. The right to landscape: contesting landscape and human rights. Ashgate, Farnham. pp 51-56.

Egoz, S., Makhzoumi, J., Pungetti, G. 2011. The right to Landscape: Contesting landscape and Human Rights. Ashgate Publishing Limited. Farnham.

E.U (2011). "Europa - Unity in diversity." http://europa.eu/about-eu/basic-information/symbols/motto/. Retrieved 10/11/2012.

ESF/COST (2010). Landscape in a changing world. bridging divides, integrating disciplines, serving society." Social Policy Breifing October, No. 41.

http://www.esf.org/index.php?elD=tx nawsecuredl\&u=0\&file=fileadmin/be user/CEO Unit/Science Policy/ES F-

COST/2010/Landscape SPB/SPB Landscape ChangingWorld.pdf\&t=1373713284\&hash=a060e2cec3f39402794 9c165bf125ae5812adde1. Retrieved 10/11/2012.

Gailing, L., Leibenath, M. (2013). "The Social Construction of Landscapes: Two Theoretical Lenses and Their Empirical Applications." Landscape Research: 1-16.

Howard, P. 2004. Spatial planning for landscape: mapping the pitfalls. Landscape Research. 29(4), 423-434. 
Howard, P. 2007. Multiple interfaces of the European Landscape Convention - The interface with Heritage. Norsk Geografisk Tidsskrift - Norwegian Journal of Geography. 61, 211-213.

Ingold, T. 2000. The perception of the environemnt. London, Routledge.

Innes, J. E. 2004. Consensus building: clarifications for the critics. Planning Theory. 3(1), 5-20.

Johnson, C., Penning-Rowsell, E., Parker, D. (2007). Natural and imposed injustices: the challenges in implementing 'fair' flood risk management policy in England. Geographical Journal. 173(4), 374-390.

Jones, M. 2007. The European Landscape Convention and the Question of Public Particpation. Landscape Research. 32(5), 613-633.

Jones, M. 2011. European Landscape and Participation - Rhetoric or Reality? The European Landscape Convention: Challenges of Participation. M. Jones and M. Stenseke. Dordrecht, Springer. 13: 27-44.

Jones, M., Daugstad, K. 1997. Usages of the "cultural landscape" concept in Norwegian and Nordic landscape administration. Landscape Research. 22(3), 267-281.

Jones, M., Stenseke, M. 2011. The issue of public participation in the European Landscape Convention. In: Jones, M., Stenseke, M. (Eds.) The European Landscape Convention: Challenges of participation. Springer, Dordrecht. pp 1-26.

Lewis, S., Pea, R., Rosen, J. 2010. Beyond participation to co-creation of meaning:mobile social media in generative learning communities. Social Science Information. 49(3), 351-369.

Majchrowska, A. 2011. The Implementation of the European Landscape Convention in Poland. In: Jones, M., Stenseke, M. (Eds.) The European Landscape Convention: Challenges of participation. Springer, Dordrecht. 8189.

Matland, R. 1995. Synthesizing the implementation literature: the ambiguity-conflict model of policy implementation. Journal of public administration research and theory. 5 (2).

Mouffe, C. 1999. Deliberative democracy or agonistic pluralism? Social Research. 66(3), 745-758.

Natural England. 2009. European Landscape Convention: Natural England's 2009/2010 Action Plan http://www.naturalengland.org.uk/Images/ELC-actionplan0910 tcm6-20278.pdf. Retreived: 11/07/2011.

Natural England and Countryscape. 2010. Landscape Character Network Database.

http://www.naturalengland.org.uk/ourwork/landscape/englands/character/lcn/nationaldatabase/default.aspx. Retreived 10/01/2013.

Nilsson, K., Åkerlund, U. Konijnendijk, C., Alekseev, A., Caspersen, O., Guldager, S., Kuznetsov, E., Mezenko, A., Selikhovkin, A. 2007. Implementing urban greening aid projects - The case of St. Petersburg, Russia. Urban Forestry \& Urban Greening 6(2), 93-101.

Nonaka, I., von Krogh. G. 2009. Tacit knowledge and knowledge conversion: controversy and advancement in organizational knowledge creation theory." Organization Science 20(3): 635-652.

Olwig, K. 2007a. Multiple interfaces of the European Landscape Convention - The European Landscape Convention as 'interface'. Norsk Geografisk Tidsskrift - Norwegian Journal of Geography. 6(214-215).

Olwig, K. R. 2007b. The practice of landscape 'Conventions' and the just landscape: The case of the European landscape convention. Landscape Research. 32(5), 579 - 594. 
Peak District National Park Authority. 2007. Peak District Landscape Character Assessment. http://www.peakdistrict.gov.uk/ data/assets/pdf file/0007/90493/lca-fullreport.pdf. Retrieved 03/07/2013.

Pedroli, B., Wascher, D., de Blust, G., Paracchini, M. L., van Doorn, A. 2007. Introduction: Europe's Living Landscapes at a Turning Point. In: B. Pedroli, A. Van Doorn, G. Be Blust (Eds.): Europe's Living Landscapes. Zeist, KNNV Publishing. pp11-18.

Planchat-Héry, C. 2011. The Prospective Vision. Integrating the Farmers' Point of View into French and belgium Local Planning. In: Jones, M., Stenseke, M. (Eds.): The European Landscape Convention: Challenges of Participation. Springer, Dordrecht. pp.175-198.

Pløger, J. 2004. Strife: Urban Planning and Antagonism. In: Hillier, J., Healey, P. (Eds.): Contemporary Movements in Planning Theory. Ashgate, Aldershot. pp 199-220.

Polanyi, M. 1966. The Tacit Dimension. Chicago, The Chicago University Press.

Prieur, M. 2006. Landscape and social, economic, cultural and ecological approaches. In: Prieur, M., Luginbuehl, Y., Zoido Naranjo, F., de Montmollin, B., Pedroli, B., van Mansvelt, J. D., Durousseau, S., Landscape and sustainable development: challenges of the European Landscape Convention. Strasbourg, Council of Europe, 11-28.

Primmer, E., Kyllönen, S. 2006. Goals for public participation implied by sustainable development, and the preparatory process of the Finnish National Forest Programme. Forest Policy and Economics. 8(8), 838-853.

Proshansky, H., A. Fabian, et al. (1983). "Place-Identity: Physical World Socialization of the Self " Journal of Environmental Psychology 3: 57-83.

Read, A. D. 1999. "A weekly doorstep recycling collection, I had no idea we could!": Overcoming the local barriers to participation. Resources, Conservation and Recycling. 26(3-4). 217-249.

Reed, M. S., Evely, A. C., Cundill, G., Fazey, I., Glass, J., Laing, A., Newig, J., Parrish, B., Prell, C., Raymond, C., Stringer, L. C. 2010. "What is social learning?" Ecology and Society. 15(4).

Rixecker, S. 2011. Re-conceptualising Human Rights in the context of climate change: utilising the Universal Declaration of Human Rights as a platform for future rights. In: Egoz, S., Makhzoumi, J., Pungetti, G. The right to landscape: contesting landscape and human rights. Ashgate, Farnham. pp. 23-38

Sack, R. D. 1997. Homo Geographicus. Baltimore, The John Hopkins University Press.

Sarlöv Herlin, I. 2007. Multiple interfaces of the European Landscape Convention - The interface with landscape ecology. Norsk Geografisk Tidsskrift - Norwegian Journal of Geography. 61, 210-211.

Sassatelli, M. 2010. European identity between flows and places: insight from emerging european landscape Policies." Sociology. 44(1), 67-83.

Sayers, R. 2006. "Principles of Awareness-Raising: information Literacy, a case study." UNESCO Bangkok, http://drtc.isibang.ac.in/xmlui/bitstream/handle/1849/290/Principles of awarenessraising Information literacy a case study by Richard Sayers.pdf?sequence=1. Retrieved - 15/06/12.

Schön, D. A. 1983. The Reflective Practitioner: How professionals think in action. Ashgate, Aldershot,

Scott, A. 2002. Assessing public perception of landscape:the LANDMAP experience. Landscape Research. 27(3), 271-295.

Scott, A. 2011. Beyond the conventional: Meeting the challenges of landscape governance within the European Landscape Convention? Journal of Environmental Management. 92(10), 2754-2762. 
Selman, P. 2004. Community participation in the planning and management of cultural landcape. Journal of Environmental Planning and Management. 47, 365 - 392.

Sevenant, M., Antrop, M. 2010."Transdisciplinary landscape planning: Does the public have aspirations? Experiences from a case study in Ghent (Flanders, Belgium). Land Use Policy. 27(2), 373-386.

Soini, K. 2004. Between Insideness and Outsideness: Studying Local's Perceptions of Landscape.In: H. Palang, S. H, M. Antrop and G. Setten. European Rural Landscapes: Persistence and Change in a Globalising Environment. Kluwer, Dordrecht. pp 83-98.

Spencer, N. 2011. Participation Within the Landscape of the River Dart Catchment, Devon, England. In Jones, M., Stenseke, M. The European Landscape Convention: Challenges of Participation. Springer, Dordrecht. pp 239-260.

Stahlschmidt, P. and V. Nellemann 2009. Metoder til Landskabsanalyse: Kortlǽgning af stedets karakter og potentiale, Forlaget Grønt Miljø

Stenseke, M. 2009. Local participation in cultural landscape maintenance: Lessons from Sweden. Land Use Policy. 26(2): 214-223.

Swanwick, C. 2002. Landscape Character Assessment, Guidance for England and Scotland. Countryside Agency, Cheltenham and Scottish Natural Heritage, Edinburgh.

Swanwick, C. 2009. Society's attitudes to and preferences for land and landscape. Land Use Policy. 26, Supplement 1(0), 62-75.

Swanwick, C., Bingham, I., Parfitt, A. 2002. Topic paper 3 - Landscape Character Assesment - How stakeholders can help. Landscape Character Assessment guidance. Countryside Agency, Cheltenham and Scottish Natural Heritage, Edinburgh.

Tilley, C. 2004. The materiality of stone: explorations in landscape phenomenology. Berg Publishers, Oxford.

Tuan, Y. 1977. Topophilia: study of environmental perception, attitude and value. Prentice-Hall, New Jersey.

UNECE 1998. Aarhus Convention Convention on Access to Information, Public Participation in Decision-making and Access to Justice on Environmental Matters. Aarhus, UNECE, United Nations Economic Commision for Europe http://www.unece.org/env/pp/. Retreived 10/05/12

Vouligny, É., Domon, G., Ruiz, J. (2009). An assessment of ordinary landscapes by an expert and by its residents: Landscape values in areas of intensive agricultural use. Land Use Policy. 26(4), 890-900. 